\title{
DNA barcoding of the tidal swamp rice (Oryza sativa) landraces from South Kalimantan, Indonesia
}

\author{
DINDIN HIDAYATUL MURSYIDIN ${ }^{1, \boldsymbol{\vartheta}}$, YUDHI AHMAD NAZARI ${ }^{2}$, BADRUZSAUFARI ${ }^{1}$, \\ MUHAMMAD RIDHO DINTA MASMITRA ${ }^{1}$ \\ ${ }^{1}$ Laboratory of Genetics and Molecular Biology, Faculty of Mathematics and Natural Sciences, Universitas Lambung Mangkurat. Jl. A. Yani Km. 36, \\ Banjarbaru 70714, South Kalimantan, Indonesia. Tel.: +62-511-4773112, `email: dindinhm@ gmail.com. \\ ${ }^{2}$ Department of Agroecotechnology, Faculty of Agriculture, Universitas Lambung Mangkurat. Jl. A. Yani Km. 36, Banjarbaru 70714, South Kalimantan, \\ Indonesia
}

Manuscript received: 16 January 2021. Revision accepted: 3 March 2021.

\begin{abstract}
Mursyidin DH, Nazari YA, Badruzsaufari, Masmitra MRD. 2021. DNA barcoding of the tidal swamp rice (Oryza sativa) landraces from South Kalimantan, Indonesia. Biodiversitas 22: 1593-1599. The tidal swamp rice (Oryza sativa L.) landraces of the South Kalimantan, Indonesia, has been known for hundred years ago with a better adaptation to the local conditions, such as acidity, salinity, and metals contamination. However, the genetic insight of these landraces has not fully understood. Here, the $r b c \mathrm{~L}$ region of tidal swamp rice from this region was successfully sequenced, aligned, analyzed, and deposited into the GenBank with accession numbers of MT818188-MT818201. The multiple alignments of these sequences showing a barcoding motif with eight mutation or polymorphic sites with both substitutions (transition-transversion) and indels (insertion-deletion). Based on this marker, the tidal swamp rice has a low genetic diversity, only 0.086. However, the UPGMA and maximum likelihood (ML) analyses revealed that this germplasm was grouped into five and twoclusters or clades, respectively. In this case, Bayar Putih is closely related to Siam Panangah and farthest from Lemo. This information might help to develop conservation and breeding programs of the tidal swamp rice landraces in the future.
\end{abstract}

Keywords: Breeding program, DNA barcoding, genetic diversity, rice, tidal swamp area

\section{INTRODUCTION}

Rice (Oryza sativa L.) is the main food crop for more than half of the world population (Ajala and Gana 2015, Sharif et al. 2014). This plant becomes an essential crop for the direct intake of calorie needs, around $20 \%$, for the population (Panesar and Kaur 2016). So it is not surprising if the rice has been distributed and cultivated in more than 100 countries, except Antarctica (Ismail 2013, Wei and Huang 2019). Even today, increasing food crop production, especially rice, continues to have endeavored in the face of a surge in world population that has increased significantly (Lenaerts et al. 2019).

Tidal swamps are potential land for rice cultivation and increasing food crop production for the future (Sinaga et al. 2014). While these lands have limitations, such as lack of nutrients, high content of iron and other metals, and salinity (Mawardi et al. 2020), it is possible to achieve high food crop production through proper technology applications. In Asia, there is still around 20.1 million ha of tidal swamps that suitable for this purpose (Kirwan and Megonigal 2013). Partially in Indonesia, there is at least 10 million ha of this land located mainly in Sumatra and Kalimantan with unique characteristics. According to Mawardi et al. (2020), tidal swamps are classifying into four categorized based on soil types, namely fluvial deposits, marine sediments, organic and aeolian soils, acid sulfate, and acid sulfate potential soils.

In general, there are some traditional rice cultivars (referred to as 'tidal swamp rice') with important genetic characteristics found from this area (Mursyidin and Khairullah 2020). While this germplasm still has generally low production, only two tonnes per ha, some cultivars show better adaptation to the local condition (Sinaga et al. 2014). For example, the 'Datu' cultivar, originating from South Kalimantan, Indonesia, produces many panicles and grains and is relatively resistant to salinity. Other cultivars from the same region, such as 'Bayar' and 'Siam Unus', show a better adaptation to acidity and metal contamination (Mursyidin et al. 2017). Hence, tidal swamp rice is a potential source of many useful genes for future rice breeding programs (Bhandari et al. 2017).

However, the genetic insight of the local rice germplasm of these areas is not generally understood. Partially in the tidal swamp areas of South Kalimantan, Indonesia, the local rice germplasm has been limited to characterized morphologically, both in macro and microstructure (Mursyidin et al. 2018a, 2019, Mursyidin and Khairullah 2020). While these markers are essential in evaluating rice germplasm, they were strongly influenced by the environmental factors (Nadeem et al. 2018). Besides, phenotypic traits have limitations such as low polymorphism and heritability, late expression, and timeconsuming to employ (Anumalla et al. 2015).

Several molecular markers have applicated to characterized the local rice germplasm, such as RAPD or random amplified polymorphic DNA (Arshad et al. 2011), AFLP or amplified fragment length polymorphism 
(Mokuwa et al. 2014, Rajkumar et al. 2011), and SSR or microsatellite (Das et al. 2013, Salgotra et al. 2015, Sutoro et al. 2015). However, these markers have also shown certain limitations, such as relatively inconsistent and subjective. Nowadays, DNA barcoding markers provide several advantages to characterized plant germplasm, such as easy to amplify, sequence, and align in most plants (Hollingsworth et al. 2011). Furthermore, this marker shows a high primer universality and generates high sequence quality or unambiguous alignment output (Dong et al. 2013). The Consortium for the Barcode of Life or CBOL (2009) proposed several DNA barcoding markers to determine plant germplasm, one of which is $r b c \mathrm{~L}$.

This study aims to determine the genetic diversity and relationship of the tidal swamp rice indigenously from South Kalimantan, Indonesia, using a DNA barcoding marker, namely $r b c \mathrm{~L}$. According to de Melo Moura et al. (2019), this marker shows universality, a high PCR amplification success, and relatively high overall sequence quality, as well as a high discriminatory power between Angiosperms. Besides, this marker has advantages over others, especially being able to distinguish germplasm that has a very close genetic relationship, like rice (Wattoo et al 2016). So, it is useful in plant population genetics and systematics studies. Further, these results are beneficial in supporting the rice breeding efforts, globally and locally.

\section{MATERIALS AND METHODS}

\section{Plant materials}

A total of 14 samples of tidal swamp rice comprise 13 from the South Kalimantan's tidal swamp areas (Figure 1). One from South Sumatra, Indonesia (an outgroup), was used in this study. The list of all rice samples and their origin is presented in Table 1.

\section{Sample preparation}

Seeds of each rice landrace were germinated after being soaked in a fungicide solution and rinsed thoroughly in warm water $\left(30-35^{\circ} \mathrm{C}\right)$. Seeds then were transplanted into pots, $30 \mathrm{~cm}$ in diameter and $20 \mathrm{~cm}$ in height, with soil collected from a paddy field. All rice samples were planted and maintained with a standard agronomic procedure, described by Sato and Uphoff (2007), in Indonesian Swamps of Agricultural Research Institute, Banjarbaru, South Kalimantan, Indonesia. Leaf samples of each rice landrace at a seedling stage were collected for DNA assay.

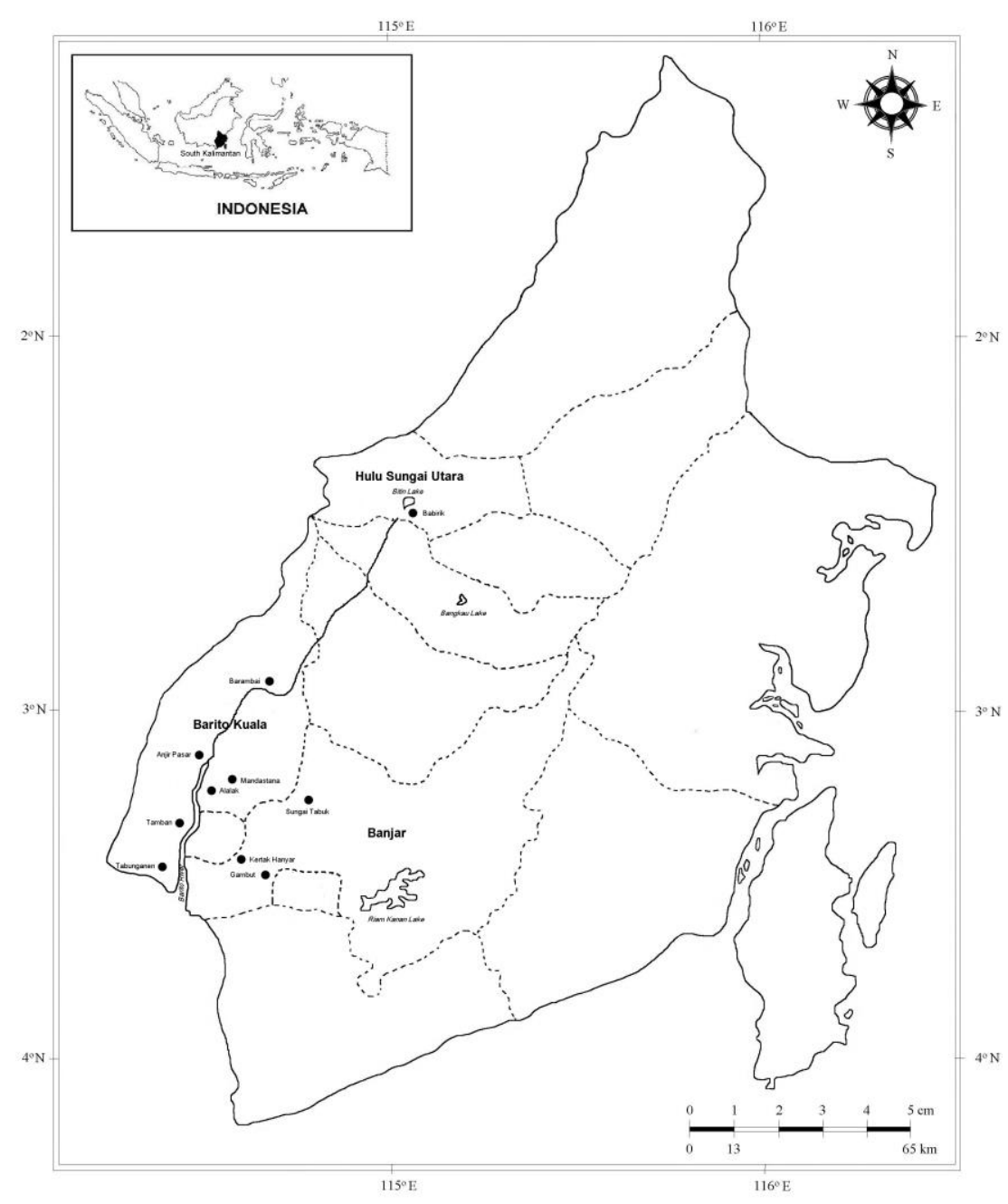

Figure 1. Map of South Kalimantan, Indonesia, showing the sampling locations (circle marked) where the tidal swamp rice collected 
Table 1. List of the tidal swamp rice landraces used in this study and their origin

\begin{tabular}{ll}
\hline Landrace & Origin (District/Province) \\
\hline Bayar Putih & Gambut, Banjar, South Kalimantan \\
Datu & Tabunganen, Barito Kuala, South Kalimantan \\
Lakatan Hirang & Barambai, Barito Kuala, South Kalimantan \\
Lemo & Alalak, Barito Kuala, South Kalimantan \\
Pandak Tinggi & Barambai, Barito Kuala, South Kalimantan \\
Randah Pandang & Tamban, Barito Kuala, South Kalimantan \\
Serai & Alalak, Barito Kuala, South Kalimantan \\
Serai Rampak* & South Sumatra \\
Siam Berandal & Gambut, Banjar, South Kalimantan \\
Siam Panangah & Gambut, Banjar, South Kalimantan \\
Siam Perak Ganal & Anjir Pasar, Barito Kuala, South Kalimantan \\
Siam Puntal & Kertak Hanyar, Banjar, South Kalimantan \\
Siam Sabar & Gambut, Banjar, South Kalimantan \\
Unus Organik & Anjir Pasar, Barito Kuala, South Kalimantan \\
\hline Note: ${ }^{*}$ an outgroup &
\end{tabular}

\section{DNA assay}

DNA was isolated from young leaves of all the rice samples using the DNAZol@Direct kit, following the manufacturer's protocol (Molecular Research Center Inc., USA). The DNA was then quantified using a UV-VIS spectrophotometer (NanoVue, GE Healthcare, UK) and amplified by a DNA barcoding marker, $r b c \mathrm{~L}$ (Table 2).

PCR reaction was carried out in the total volume of 25 $\mu \mathrm{L}$ (consisting of $20 \mathrm{ng}$ genomic DNA $(2 \mu \mathrm{L}), 0.2 \mu \mathrm{mol}$ for each primer $(1 \mu \mathrm{L}$ ), and $22 \mu \mathrm{L}$ of PCR mix (MyTaq HS Red Mix, Bioline, UK). This reaction was employed following the Gholave et al. (2017) procedure, with an initial denaturation at $94^{\circ} \mathrm{C}$ for $5 \mathrm{~min}$; followed by 35 cycles of denaturation at $94^{\circ} \mathrm{C}$ for $30 \mathrm{sec}$, annealing at $48^{\circ} \mathrm{C}$ for $30 \mathrm{sec}$, and extension at $72^{\circ} \mathrm{C}$ for $45 \mathrm{sec}$; and a final extension at $72^{\circ} \mathrm{C}$ for $7 \mathrm{~min}$. The amplified DNA fragments were then separated by $2 \%$ agarose gel electrophoresis with a 1X TBE buffer solution, stained with a DNA dye (GelRed, Biotium Inc., USA), and observed on UV transilluminator light, as well as documented using a digital camera. DNA fragments that were successfully amplified were then sent to $1^{\text {st }}$ Base Ltd., Malaysia, for purification and sequencing bidirectional using the Sanger method. All sequences were deposited in GenBank with accession numbers of MT818188-MT818201.

\section{Data analysis}

To obtain a consensus sequence, nucleotide sequences of the tidal swamp rice were aligned and refined manually using the Molecular Evolutionary Genetics Analysis (MEGA-X) ver. 10.1 software (Kumar et al. 2018). The homology of this consensus was traced initially using the
Basic Local Alignment Search Tool (BLAST) software (Kumar et al. 2018), which included in the GenBank website (https://blast.ncbi.nlm.nih.gov/Blast.cgi). All sequences were then aligned using Multalin software (Corpet 1988). The genetic diversity and relationship of the rice germplasm were analyzed using the MEGA-X software (Kumar et al. 2018). The UPGMA and maximum likelihood (ML) methods were chosen to reconstruct genetic relationships. The topological robustness of the relationships was then evaluated by the bootstrap analysis with 1000 replicates (Lemey et al. 2009).

\section{RESULTS AND DISCUSSION}

\section{The $r b c \mathrm{~L}$ sequence of tidal swamp rice and its genetic diversity}

The $r b c \mathrm{~L}$ sequence of the tidal swamp rice from South Kalimantan, Indonesia, has unique characteristics. Following Figure 2 and Table 3, these sequences have different nucleotide lengths, ranging from 606-609 bp. In this case, the most extended nucleotide (609 bp) was shown by Lemo and Serai Rampak (outgroup), whereas the shortest (606 bp) by Pandak Tinggi. According to Clegg (1993), the complete sequence of this gene approximately 1400 nucleotides in length, and it varies slightly among different flowering plant genera. In other words, this gene has high homology among different plant genera (Dong et al. 2013). Singh and Banerjee (2018) reported that this gene has an intergenic spacer with 600-800 nucleotides.

Following Figure 2 and Table 3, these sequences also show some mutational evens, both indels (insertiondeletion) and substitutions (transition-transversion). In general, eight mutations or polymorphic sites are recorded for these sequences (Table 3). The deletion shows in the $13^{\text {th }}$ and $563^{\text {rd }}$ position of the $r b c \mathrm{~L}$ sequence, whereas the insertion shows in the $548^{\text {th }}, 553^{\text {rd }}, 563^{\text {rd }}$, and $569^{\text {th }}$. Furthermore, the transversion showed in the $567^{\text {th }}$ and $575^{\text {th }}$, and transition in $569^{\text {th }}$ (Table 4).

Table 3. Genetic information of $r b c \mathrm{~L}$ sequences of tidal swamp rice from the South Kalimantan, Indonesia

\begin{tabular}{ll}
\hline Parameter & $\boldsymbol{r b c \mathbf { L }}$ \\
\hline Range of sequence length (bp) & $605-609$ \\
Number of polymorphic sites $(S)$ & 8 \\
Bayesian information criterion (BIC) & 2014.448 \\
Akaike information criterion (AICc) & 1831.365 \\
Maximum likelihood value (InL) & -889.600 \\
Transition/transversion bias value $(R)$ & 0.67 \\
GC content $(\%)$ & 43.67 \\
Nucleotide diversity $(\pi \%)$ & 0.086 \\
\hline
\end{tabular}

Table 2. A pair of primers used in the study (Gholave et al. 2017)

\begin{tabular}{lllcc}
\hline Region & Position & Sequence (5'-3') & Annealing $\left({ }^{\circ} \mathbf{C}\right)$ & Target $(\mathbf{b p})$ \\
\hline \multirow{2}{*}{$r b c \mathrm{~L}$} & Forward & ATGTCACCACAAACAGAGACTAAAGC & \multirow{2}{*}{600} \\
& Reverse & GTAAAATCAAGTCCACCRCG & & \multirow{2}{*}{600} \\
\hline
\end{tabular}




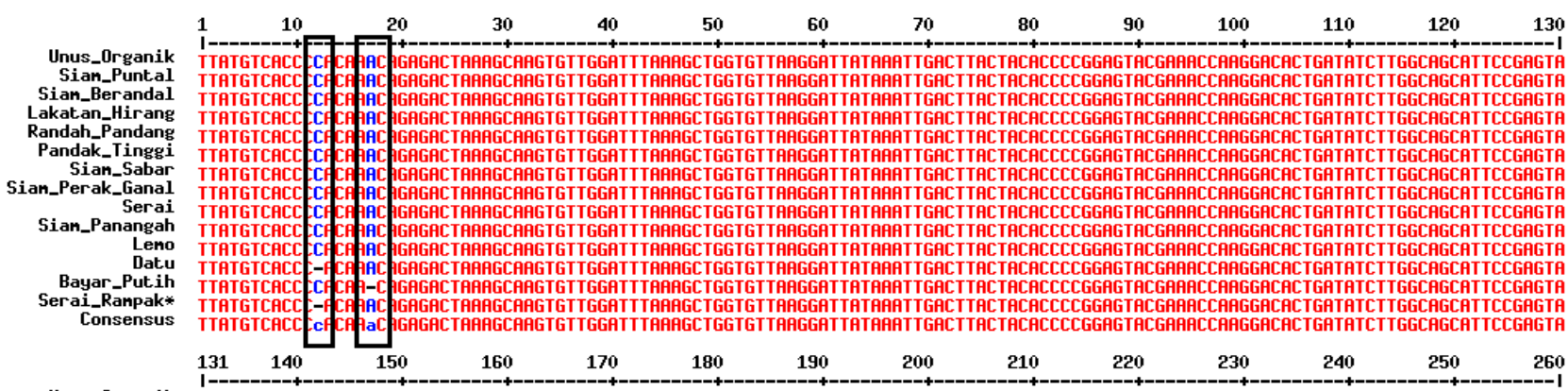

Unus_Organik ACTCCTCAGCCGGGGGTTCCGCCCGAAGAAGCAGGGCTGCAGTAGCTGCCGAATCTTCTACTGGTACATGGACARCTGTTTGGACTGATGGACTTACCAGTCTTGATCGTTACARAGGCCGATGCTATC

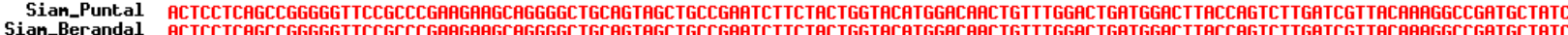

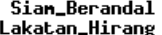
ACTCCTCAGCCGGGGGTTCCGCCCGAAGAAGCAGGGGCTGCAGTAGCTGCCGAATCTTCTACTGGTACATGGACAACTGTTTGGACTGATGGACTTACCAGTCTTGATCGTTACAAAGGCCGATGCTATC ACTCCTCAGCCGGGGGTTCCGCCCGAAGAAGCAGGGGCTGCAGTAGCTGCCGAATCTTCTACTGGTACATGGACAACTGTTTGGACTGATGGACTTACCAGTCTTGATCGTTACAAAGGCCGATGCTATC ACTCCTCAGCCGGGGGTTCCGCCCGAAGAAGCAGGGGCTGCAGTAGCTGCCGAPTCTTCTACTGGTACATGGACAACTGTTTGGACTGATGGACTTACCAGTCTTGATCGTTACAAAGGCCGATGCTATC ACTCCTCAGCCGGGGGTTCCGCCCGAAGAAGCAGGGGCTGCAGTAGCTGCCGAATCTTCTACTGGTACATGGACAACTGTTTGGACTGATGGACTTACCAGTCTTGATCGTTACAAFGGCCGATGCTATC ACTCCTCAGCCGGGGGTTCCGCCCGAAGAAGCAGGGGCTGCAGTAGCTGCCGAATCTTCTACTGGTACATGGACAACTGTTTGGACTGATGGACTTACCAGTCTTGATCGTTACAAAGGCCGATGCTATC ah

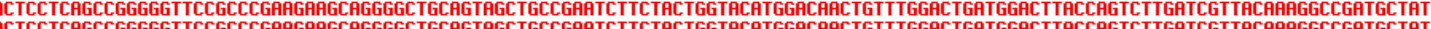
ACTCCTCAGCCGGGGGTTCCGCCCGAFGAFGCAGGGGCTGCAGTAGCTGCCGAATCTTCTACTGGTACATGGGCAACTGTITGGACTGATGGACTTACCAGTCTTGATCGTTACAAAGGCCGATGCTATC

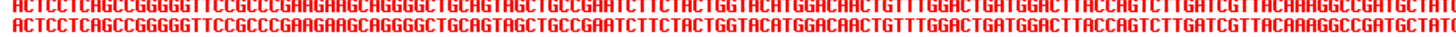

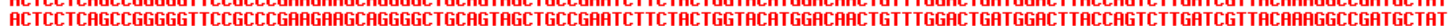

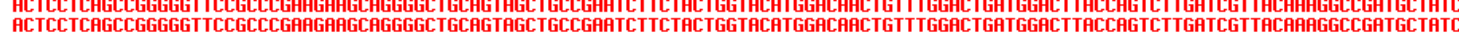

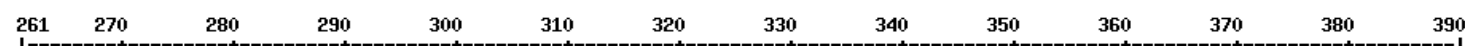

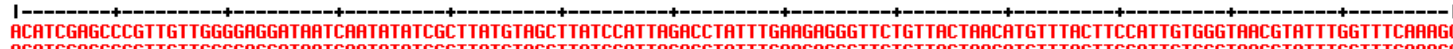

Unus_Organik

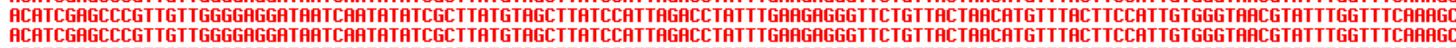
ACATCGAGCCCGTTGTTGGGGGGGATAATCAATATATCGCTTATGTAGCTTATCCATTAGACCTATTTGGAGGGGGTTCTGTTACTARCATGTTTACTTCCATTGTGGGTARCGTATTTGGTTTCARAGC

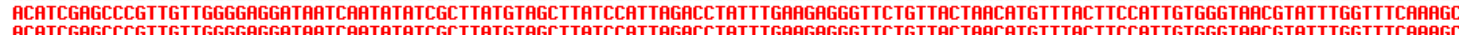

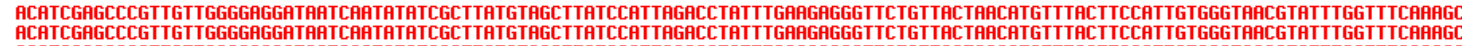
ACATCGAGCCCGG ACA ACATCGAGCCGTTITGGGGG

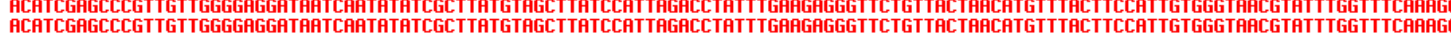
ACATCGAGCCCGTTGTTGGGGAgGATAATCAATATATCGCTTATGTAGCTTATCCATTAGACCTATTTGAAGAGGGGTTCTGTTACTAACATGTTTACTTCCATTGTGGGTAACGTATTTGGTTTCAAAGG

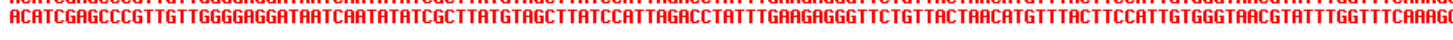

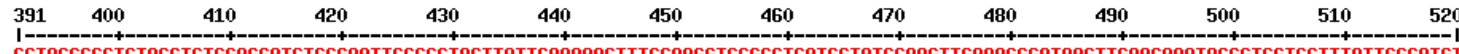

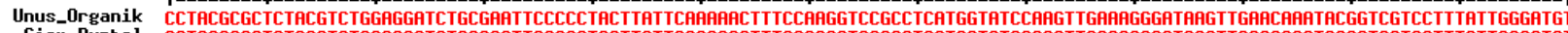

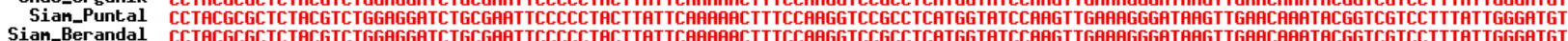
Sian_Berandal
Lakatan_Hirang

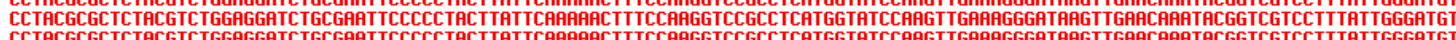

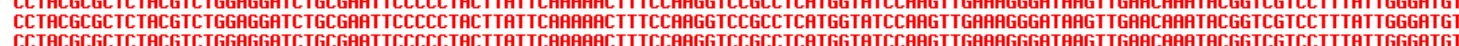

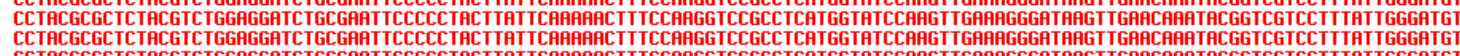

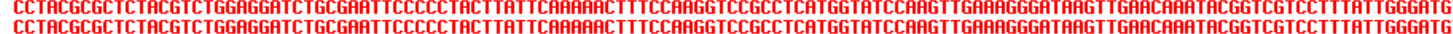
CCTACGCGCTCTACGTCT

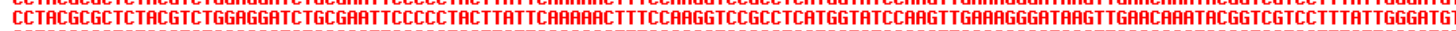

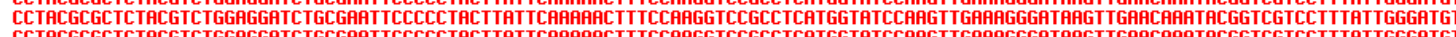

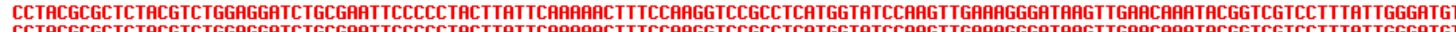

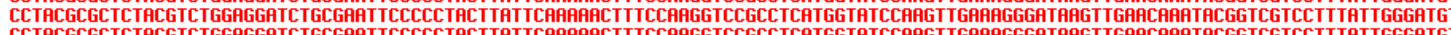

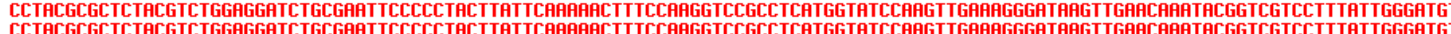

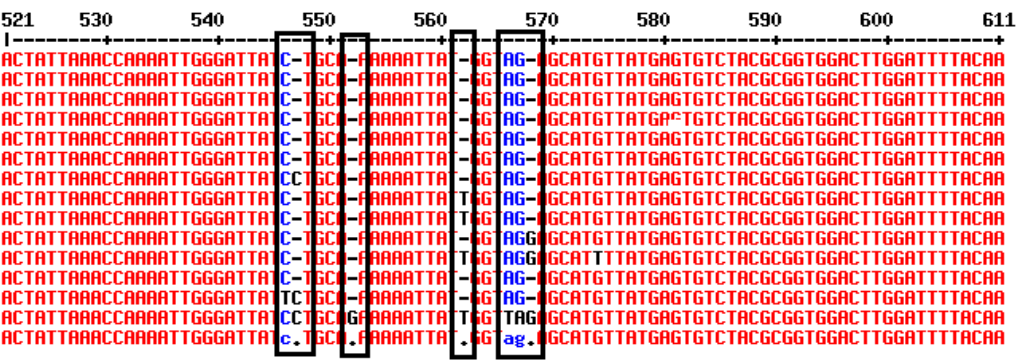

Figure 2. Multiple alignment of the $r b c \mathrm{~L}$ sequence of tidal swamp rice and their mutational evens (closed rectangle)

According to Clegg (1993), these mutations are sometimes found in most grasses and other plant species, such as the Orchidales, Liliales, Bromeliales, and Arecales, with a low mutation rate. CBOL (2009) reported that the genus Oryza has partial nucleotide sequences of the gene with a low mutation rate. In another study, however, the $r b c \mathrm{~L}$ exhibited a high efficiency of inter/intrageneric levels, particularly in Cupressaceae, Cornaceae, Ericaceae, Graniaceae (Singh and Banerjee 2018). Dong et al. (2013) also reported that the $r b c \mathrm{~L}$ gene represents the differences in mode and tempo of molecular evolution, whether in
Angiosperm, monocotyledons, and Gramineae.

Referred to Frankham et al. (2004), these mutational evens contributed to genetic diversity. In this study, the tidal swamp rice landraces of South Kalimantan, Indonesia, showed a relatively low genetic diversity, only 0.086 (Table 3). Following Furlan et al. (2012), low level of genetic diversity caused by reductions in population size and absence of gene flow. The best feature of these two factors in rice described by Thomas et al. (2017) and Wang et al. (2017). 
Table 4. Polymorphism (mutations) in the aligned sequence of the $r b c \mathrm{~L}$ of tidal swamp rice landraces

\begin{tabular}{|c|c|c|c|c|c|c|c|c|}
\hline \multirow{2}{*}{ Landrace } & \multicolumn{8}{|c|}{ Nucleotide Position } \\
\hline & $13^{a}$ & $\mathbf{5 4 8}^{\mathrm{b}}$ & $553^{b}$ & $563^{b}$ & $567^{\mathrm{c}}$ & $568^{\mathrm{d}}$ & $569^{b}$ & $575^{c}$ \\
\hline Lakatan Hirang & $\mathrm{C}$ & - & - & - & A & G & - & G \\
\hline Siam Berandal & $\mathrm{C}$ & - & - & - & A & $\mathrm{G}$ & - & $\mathrm{G}$ \\
\hline Pandak Tinggi & $\mathrm{C}$ & - & - & - & A & $\mathrm{G}$ & - & G \\
\hline Randah Pandang & $\mathrm{C}$ & - & - & - & A & $\mathrm{G}$ & - & G \\
\hline Unus Organik & $\mathrm{C}$ & - & - & - & A & $\mathrm{G}$ & - & $\mathrm{G}$ \\
\hline Siam Sabar & $\mathrm{C}$ & $\mathrm{C}$ & - & - & A & $\mathrm{G}$ & - & $\mathrm{G}$ \\
\hline Lemo & $\mathrm{C}$ & - & - & $\mathrm{T}$ & A & $\mathrm{G}$ & $\mathrm{G}$ & $\mathrm{T}$ \\
\hline Serai & $\mathrm{C}$ & - & - & $\mathrm{T}$ & A & $\mathrm{G}$ & - & $\mathrm{G}$ \\
\hline Siam Perak Ganal & $\mathrm{C}$ & - & - & $\mathrm{T}$ & A & $\mathrm{G}$ & - & G \\
\hline Serai Rampak* & - & $\mathrm{C}$ & G & $\mathrm{T}$ & $\mathrm{T}$ & $\mathrm{A}$ & $\mathrm{G}$ & G \\
\hline Concensus & $\mathrm{C}$ & - & - & $\mathrm{T}$ & A & $\mathrm{G}$ & - & $\mathrm{G}$ \\
\hline
\end{tabular}

Note. ${ }^{*}$ An outgroup, ${ }^{\text {a }}$. deletion, ${ }^{\text {b }}$. insertion, ${ }^{\text {c. }}$ substitution-transversion, ${ }^{\text {d. }}$. substitution-transition.

However, compared to other studies using a similar marker, this germplasm showed higher genetic diversity than Elymus and Pseudoroegneria, for example, with genetic diversity of 0.034 and 0.074 , respectively (Dong et al. 2013). Using the IGS and trnL-F markers, Mursyidin et al. (2018b) reported that the tidal swamp rice is also showed a high nucleotide diversity of 0.61 and 0.58 , respectively.

In brief, information on genetic diversity is valuable in supporting the rice conservation and breeding programs in the future (Acquaah 2012). In this case, genetic diversity serves to provide a baseline population for natural selection and an integral part of evolution (Nei 2007). In other words, it was required for populations to adapt to the environmental changes (Frankham et al. 2004). Conversely, the mutation is an initial step in the formation of a baseline population and subsequent increase in population genetic diversity (Hodge 2010, Ripley 2013).

\section{Phylogenetic relationships}

The phylogenetic analysis revealed that the tidal swamp rice from South Kalimantan, Indonesia has a unique relationship. In general, the germplasms were separated into five clusters by UPGMA and two clades via ML (Figure 3). Interestingly, both analyses implicated the separation of tidal swamp rice from South Kalimantan to Sumatra (outgroup). Based on UPGMA analysis (Figure 3A), the Lemo and Siam Puntal cultivars are divided separately into groups III and IV. Meanwhile, Siam Putih and Siam Panangah belong to a similar group (II). In this case, the first cluster (I) is the group with the largest cultivar members.

Based on the ML analysis (Figure 3B), all tidal swamp rice landraces from this region are incorporate into clade I. However, Bayar Putih, Siam Puntal, and Lemo show apomorphy characters. It means, although the three landraces are in the same clade as the other eight landraces of South Kalimantan (ingroup), they have a more advanced level of evolution. In this study, Serai Rampak (outgroup) showed plesiomorphic characters because these landrace's position was outside the clade. According to Wilberg (2015), outgroup sampling is of primary importance in phylogenetic analyses because it can affect ingroup relationships and polarizing characters.

Following UPGMA, Bayar Putih is closely related to Siam Panangah and farthest from Lemo. Meanwhile, the previous study by Mursyidin et al. (2018b) revealed that Bayar Putih has the closest relationship with Siam Mutiara and farthest to Lakatan Pacar. In-plant breeding, the farthest genetic groups are considered to produce high or wide genetic diversity. Conversely, the crossing of parents with close genetic relationships tends to avoid because it can produce offsprings with low or narrow genetic diversity, known as inbreeding (Acquaah 2012). In other words, information about genetic relationships is useful for breeders in developing new cultivars with desired traits.

\section{Future prospect}

Especially for rice development in swamps, several morphological characters are considered, such as plant height, stem diameter, and yield. Based on our previous research (Mursyidin and Khairullah 2020), Bayar Papuyu is the cultivar with the largest stem diameter, while Lakatan Putih produces the most panicles. Hence, the results of molecular characterization using this marker expected to complement existing morphological data. Conceptually, morphological characters are representations or the interaction results between molecular characters and their environment $(\mathrm{Xu}$ 2013). Thus, the application of other, more specific molecular markers, such as SNP, is expected to reveal the potential for local rice genetic diversity in this region. 

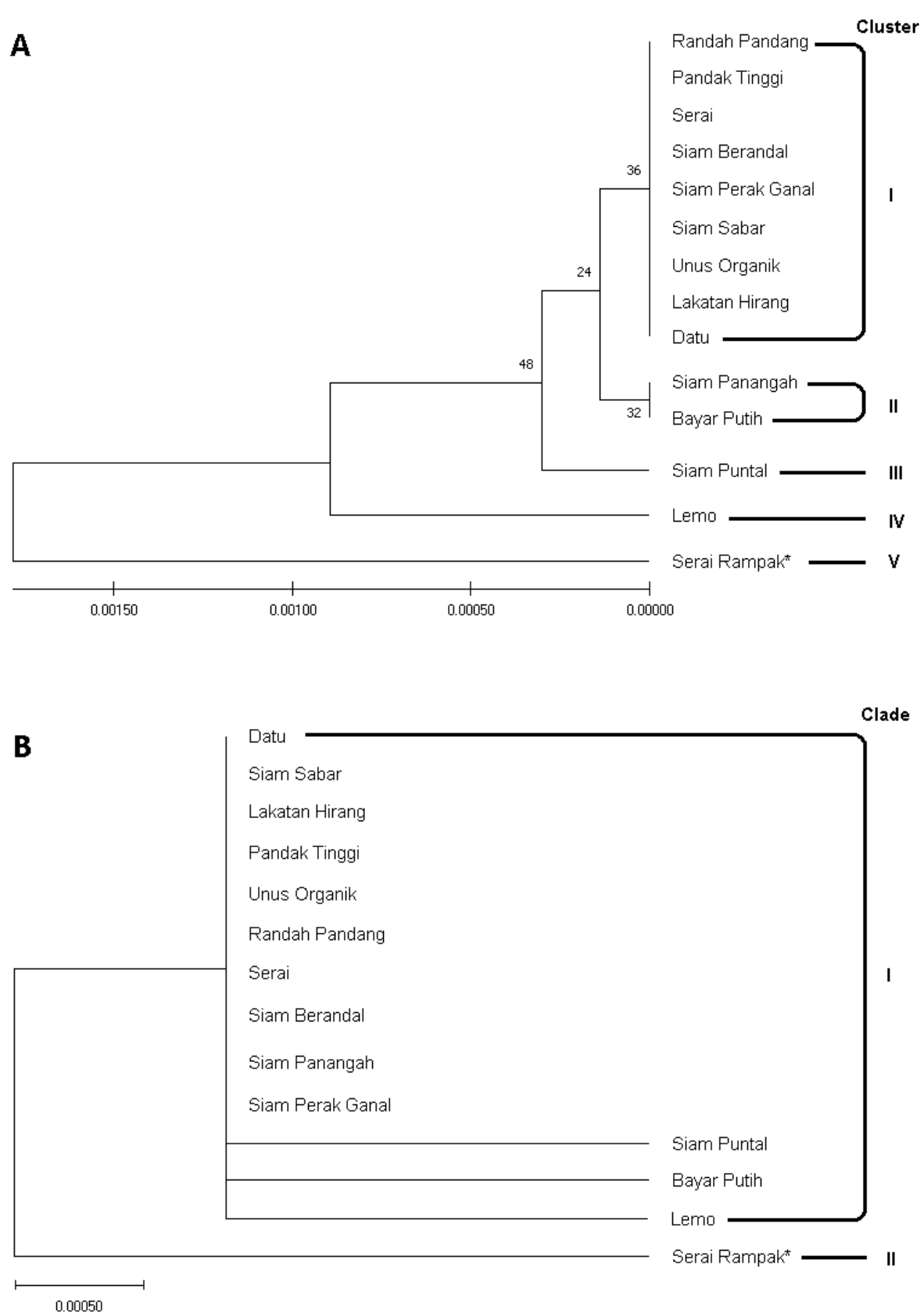

Figure 3. The genetic relationships of tidal swamp rice landraces indigenously from the South Kalimantan, Indonesia, generated by UPGMA (A) and ML (B).

\section{ACKNOWLEDGEMENTS}

The authors wish to thank the Director of the Indonesian Swampland Agriculture Research Institute, South Kalimantan, Indonesia, and a staff, Dr. Ir. Izhar Khairullah, for providing Serai Rampak as an outgroup. We are grateful to M. Aldy Hernanda for helping the molecular analysis. This study was funded by the internal research grant of Universitas Lambung Mangkurat, Indonesia (No. 023.17.2.6777518/2020 or No. 701/UN8/PP/2020) for 2020.

\section{REFERENCES}

Acquaah G. 2012. Principles of Plant Genetics and Breeding. Second Edition. John Wiley and Sons Inc., New York, USA

Ajala AS, Gana A. 2015. Analysis of challenges facing rice Processing in Nigeria. J Food Process 8: 1-6. DOI: 10.1155/2015/893673.

Anumalla M, Roychowdhury R, Geda CK, Mazid M, Rathoure AK. 2015. Utilization of plant genetic resources and diversity analysis tools for sustainable crop improvement with special emphasis on rice. Intl $\mathbf{J}$ Adv Res 3 (3): 1155-1175.

Arshad S, Iqbal A, Nawaz S, Ahmed N. 2011. Genetic diversity studies of coarse and fine rice using RAPD markers. Front Agric China 5 (2): 129-134. DOI: $10.1007 / \mathrm{s} 11703-011-1106-2$ 
Bhandari HR, Bhanu AN, Srivastava K, Singh MN, Shreya, Hemantaranjan A. 2017. Assessment of genetic diversity in crop plants - an overview. Adv Plants Agric Res 7 (3): 279-286. DOI: 10.15406/apar.2017.07.00255

CBOL. 2009. A DNA barcode for land plants. PNAS 106 (31): 12794 12797. DOI: $10.2307 / 40484604$.

Clegg MT. 1993. Review and the study of plant evolution. Proc Natl Acad Sci 90 (2): 363-367. DOI: 10.1073/pnas.90.2.363.

Corpet F. 1988. Multiple sequence alignment with hierarchical clustering Nucleic Acids Res 16 (22): 10881-10890. DOI 10.1093/nar/16.22.10881

Das B, Sengupta S, Parida SK, Roy R, Ghosh M, Prasad, Ghose TK. 2013. Genetic diversity and population structure of rice landraces from Eastern and North Eastern States of India. BMC Genet 14 (71): 1-14. DOI: $10.1186 / 1471-2156-14-71$

de Melo Moura C, Brambach F, Bado KJH, Krutovsky KV, Kreft H, Tjitrosoedirdjo SS, Siregar IZ, Gailing O. 2019. Integrating DNA barcoding and traditional taxonomy for the identification of dipterocarps in remnant lowland forests of Sumatra. Plants 8 (461): 114. DOI: $10.3390 /$ plants8110461

Dong Z, Fan X, Sha L, Zeng J, Wang Y, Chen Q, Kang H-Y, Zhang H-Q, Zhou Y-H. 2013. Phylogeny and molecular evolution of the $r b c \mathrm{~L}$ gene of Stgenome in Elymus sensu lato (Poaceae: Triticeae). Biochem Syst Ecol 50: 322-330. DOI: 10.1016/j.bse.2013.05.005

Frankham R, Ballou JD, Briscoe DA. 2002. Introduction to Conservation Genetics. Cambridge University Press, Cambridge, UK.

Furlan E, Stoklosa J, Griffiths J, Gust N, Ellis R, Huggins RM, Weeks AR. 2012. Small population size and extremely low levels of genetic diversity in island populations of the platypus, Ornithorhynchus anatinus. Ecol Evol 2 (4) :844-857. DOI: 10.1002/ece3.195.

Gholave AR, Pawar KD, Yadav SR, Bapat VA, Jadhav JP. 2017. Reconstruction of molecular phylogeny of closely related Amorphophallus species of India using plastid DNA marker and fingerprinting approaches. Physiol Mol Biol Plants 23 (1): 155-167. DOI: $10.1007 / \mathrm{s} 12298-016-0400-0$

Hodge R. 2010. Genetics and Evolution: Developmental Biology, from A Cell to An Organism. Facts on File, Inc., New York, USA

Hollingsworth PM, Graham SW, Little DP. 2011. Choosing and using a plant DNA barcode. PLoS One 6 (5): 1-13. DOI 10.1371/journal.pone.0019254

Ismail AM. 2013. Flooding and submergence tolerance. Genomics Breed Clim Crop 2: 269-290.

Kirwan ML, Megonigal JP. 2013. Tidal wetland stability in the face of human impacts and sea-level rise. Nature 504 (7478): 53-60. DOI 10.1038 /nature12856.

Kumar S, Stecher G, Tamura K. 2018. MEGA X: molecular evolutionary genetics analysis across computing platforms. Mol Biol Evol 35 (6): 1547-1549. DOI: 10.1093/molbev/msy096

Lemey P, Salemi M, Vandamme AM. 2009. The Phylogenetic Handbook: A Practical Approach to Phylogenetic Analysis and Hypothesis Testing. 2nd ed. Cambridge University Press, Cambridge, UK.

Lenaerts B, Collard BCY, Demont M. 2019. Review: Improving global food security through accelerated plant breeding. Plant Sci 287 (110207): 1-8. DOI: 10.1016/j.plantsci.2019.110207.

Mawardi, Sunarminto BH, Purwanto HB, Sudira P, Gunawan T. 2020. The influence of tidal on $\mathrm{Fe}$ distribution at tidal swamp rice-farming in Barito River area, South Kalimantan, Indonesia. BIO Web of Conf EDP Sci. DOI: 10.1051/bioconf/20202002002.

Mokuwa A, Nuijten E, Okry F, Teeken B, Maat H, Richards P, Struik PC. 2014. Processes underpinning development and maintenance of diversity in rice in West Africa: evidence from combining morphological and molecular markers. PLoS ONE 9 (1): 1-20. DOI: 10.1371/journal.pone.0085953.

Mursyidin DH, Nazari YA, Daryono BS. 2017. Tidal swamp rice cultivars of South Kalimantan Province, Indonesia: A case study of diversity and local culture. Biodiversitas 18 (1): 427-432. DOI: 10.13057/biodiv/d180155.

Mursyidin DH, Purnomo P, Sumardi I, Daryono BS. 2018a. Molecular diversity of tidal swamp rice (Oryza sativa L.) in South Kalimantan, Indonesia. Diversity 10 (22): 1-10. DOI: 10.3390/d10020022.
Mursyidin DH, Sumardi I, Purnomo, Daryono BS. 2018b. Pollen diversity of the tidal swamp rice (Oryza sativa L.) cultivars collected from South Kalimantan, Indonesia. Aust J Crop Sci 12 (03): 380-385.

Mursyidin DH, Purnomo, Sumardi I, Daryono BS. 2019. Phenotypic diversity of the tidal swamp rice (Oryza sativa L.) germplasm from South Kalimantan, Indonesia. Aust J Crop Sci 13 (03): 386-394.

Mursyidin DH, Khairullah I. 2020. Genetic evaluation of tidal swamp rice from South Kalimantan, Indonesia based on the agro-morphological markers. Biodiversitas 21 (10): 4795-4803. DOI: 10.13057/biodiv/d211045.

Nadeem MA, Nawaz MA, Shahid MQ, Doğan Y, Comertpay G, Yıldız M, Hatipoglu R, Ahmad F, Alsaleh A, Labhane N, Ozkan H, Chung G, Baloch FS. 2018. DNA molecular markers in plant breeding: current status and recent advancements in genomic selection and genome editing. Biotechnol Equip 32 (2): 261-285. DOI: 10.1080/13102818.2017.1400401

Nei M. 2007. The new mutation theory of phenotypic evolution. PNAS 104 (30): 12235-12242. DOI: 10.1073/pnas.0703349104.

Panesar PS, Kaur S. 2016. Rice: Types and Composition. In: Encyclopedia of Food and Health. 1st ed. Elsevier Ltd., Nederland.

Rajkumar G, Weerasena J, Fernando K, Liyanage A. 2011. Assessment of genetic diversity among Sri Lankan rice varieties by AFLP markers. Plant Genet Res 9 (2): 224-228. DOI:10.1017/S1479262111000256.

Ripley LS. 2013. Mutation. In: Brenner's Encyclopedia of Genetics. 2nd ed. Elsevier Inc., Nederland.

Salgotra RK, Gupta BB, Bhat JA, Sharma S. 2015. Genetic diversity and population structure of Basmati rice (Oryza sativa L.) germplasm collected from North-Western Himalayas using trait linked SSR markers. PLoS ONE 10 (7): 1-19. DOI: 10.1371/journal.pone.0131858.

Sato S, Uphoff N. 2007. A review of on-farm evaluations of system of rice intensification methods in Eastern Indonesia. CAB Rev Perspect Agric Vet Sci Nutr Nat Resour 2 (054): 1-13. DOI: 10.1079/PAVSNNR20072054.

Sharif MK, Butt MS, Anjum FM, Khan SH. 2014. Rice bran: A novel functional ingredient. Crit Rev Food Sci Nutr 54 (6): 807-816. DOI: 10.1080/10408398.2011.608586.

Sinaga PH, Trikoesoemaningtyas, Sopandie D, Aswidinnoor H. 2014 Screening of rice genotypes and evaluation of their ratooning ability in tidal swamp area. Asian J Agric Res 8 (5): 218-233.

Singh J, Banerjee S. 2018. Utility of DNA barcoding tool for conservation and molecular identification of intraspecies of rice genotypes belonging to Chhattisgarh using $r b c \mathrm{~L}$ and mat K gene sequences. Plant Arch 18: 69-75.

Sutoro P, Lestari, Reflinur, Kurniawan H. 2015. Genetic diversity of upland rice landraces from Java Island as revealed by SSR markers. Indones J Agric Sci 16 (1): 1-10. [Indonesian]

Thomas E, Tovar E, Villafañe C, Bocanegra JL, Moreno R. 2017. Distribution, genetic diversity and potential spatiotemporal scale of alien gene flow in crop wild relatives of rice (Oryza spp.) in Colombia. Rice 10 (1): 1-16. DOI: 10.1186/s12284-017-0150-9.

Wang H, Vieira FG, Crawford JE, Chu C. 2017. Asian wild rice is a hybrid swarm with extensive gene flow and feralization from domesticated rice. Genome Res 27 (6): 1-10. DOI: $10.1101 / \mathrm{gr} .204800 .116$

Wattoo JI, Saleem MZ, Shahzad MS, Arif A, Hameed A, Saleem M. 2016. DNA barcoding: amplification and sequence analysis of $r b c \mathrm{~L}$ and $m a t \mathrm{~K}$ genome regions in three divergent plant species. Adv Life Sci 4 (1): 3-7.

Wei X, Huang X. 2019. Origin, taxonomy, and phylogenetics of rice. In: Rice. AACCI International \& Elsevier Inc., Nederland.

Wilberg E. 2015. What's in an outgroup? The impact of outgroup choice on the phylogenetic position of Thalattosuchia (Crocodylomorpha) and the origin of Crocodyliformes. Syst Biol 64 (4): 621-637. DOI: 10.1093/sysbio/syv020.

Xu S. 2013. Principles of Statistical Genomics. Springer, New York, USA. 